\title{
ANOMALOUS RADIOCARBON AGES FOUND IN CAMPANIAN IGNIMBRITE DEPOSIT OF THE MEDITERRANEAN DEEP-SEA CORE CT85-5
}

\author{
Irka Hajdas $^{1,2}$ • Carla Taricco ${ }^{3}$ Georges Bonani ${ }^{1}$ • Jürg Beer ${ }^{4}$ - Stefano M Bernasconi ${ }^{5} \bullet$ \\ Lukas Wacker ${ }^{1}$
}

\begin{abstract}
A detailed radiocarbon chronology has been established for the deep-sea core CT85-5 from the Tyrrhenian Sea. This chronology, which is based on the analysis of foraminifera shells, shows a set of reversed ${ }^{14} \mathrm{C}$ ages for sediments deposited during the eruption of the Campanian Ignimbrite $(\sim 0 \mathrm{ka}$ cal BP$)$. The anomalous young ${ }^{14} \mathrm{C}$ ages coincide with elevated concentrations of ${ }^{10} \mathrm{Be}$ measured in the same core. Although reversals in ${ }^{14} \mathrm{C}$ ages have been previously found in other records at $40 \mathrm{ka}$ cal BP, such extreme changes have not been observed elsewhere. The enhancement in ${ }^{14} \mathrm{C}$ concentration in CT85-5 sediments associated with the Campanian Ignimbrite is equivalent to an apparent age $\sim 15$ ka younger than the age for the sediments deposited shortly before the eruption. Here, we present consistent results of repeated measurements showing no analytical problems that can explain the observed rapid changes in ${ }^{14} \mathrm{C}$ of this particular record.
\end{abstract}

\section{STUDY BACKGROUND}

The detection of the "10 Be peak" dated to 35 and $40 \mathrm{ka}$ BP found in Antarctic ice cores (Raisbeck et al. 1987) and later in Greenland ice cores (Yiou et al. 1997) prompted studies of variable production rates of cosmogenic isotopes. The low geomagnetic field of the Laschamp event, which was first discovered in a lava flow of the Massif Central, France (Bonhommet and Zähringer 1969), and dated to $\sim 40 \mathrm{ka}$ cal BP (see Valet et al. 2007 for a review) and more recently to $40.65 \pm 0.65 \mathrm{ka}$ cal BP (Singer et al. 2009), has been discussed as the most likely cause of these changes. In the 1990s, measurements of ${ }^{10} \mathrm{Be}$ concentrations in deep-sea sediments became available showing enhanced ${ }^{10} \mathrm{Be}$ levels around $40 \mathrm{ka} \mathrm{cal} \mathrm{BP} \mathrm{(McHargue} \mathrm{et} \mathrm{al.} \mathrm{1995,} \mathrm{2000;} \mathrm{Robinson} \mathrm{et} \mathrm{al.} \mathrm{1995).} \mathrm{Finally,} \mathrm{reconstruc-}$ tions of geomagnetic field intensity in deep-sea sediments (Laj et al. 2000, 2002) and correlation with the ice-core record of cosmogenic isotopes ${ }^{10} \mathrm{Be}$ and ${ }^{36} \mathrm{Cl}$ has shown that the intervals of low geomagnetic field coincided with periods of increased flux of cosmogenic isotopes (Baumgartner et al. 1998; Wagner et al. 2000).

Castagnoli et al. (1995) published ${ }^{10} \mathrm{Be}$ measurements on sediment core CT85-5 recovered from the Tyrrhenian Sea. The detection of a clear ${ }^{10} \mathrm{Be}$ peak, which was coincident with the Campanian Ignimbrite $(\mathrm{CI})$ ash layer, gave the background to our radiocarbon analysis across the sediment core and in particular the section corresponding to the ${ }^{10} \mathrm{Be}$ enhancement. The surprising results of our ${ }^{14} \mathrm{C}$ dating were first reported as a figure in Giaccio et al. (2006). In this study, we present the complete set of the results including all the tests carried out to assess the validity of the accelerator mass spectrometry (AMS) ${ }^{14} \mathrm{C}$ dating performed on the planktonic foraminifera shells of CT85-5 core. These results show that the high ${ }^{14} \mathrm{C}$ content coincides with the previously observed ${ }^{10} \mathrm{Be}$ enhancement (Castagnoli et al. 1995). The detailed ${ }^{14} \mathrm{C}-{ }^{10} \mathrm{Be}$ comparison is allowed by using measurements of these 2 cosmogenic radioisotopes in the same core.

\footnotetext{
${ }^{1}$ Laboratory of Ion Beam Physics, ETH, Schafmattstrasse 20, 8093 Zürich, Switzerland.

${ }^{2}$ Corresponding author. Email: hajdas@phys.ethz.ch.

${ }^{3}$ Department of Physics, University of Turin and IFSI-INAF, Turin, Italy.

${ }^{4}$ Eawag, Swiss Federal Institute of Aquatic Science and Technology, 8600 Dübendorf, Switzerland.

${ }^{5}$ Department of Geology, ETH, Sonneggstrasse 5, 8092 Zürich, Switzerland.
} 


\section{MATERIALS AND METHODS}

The core CT85-5 was recovered from the Tyrrhenian Sea $\left(40^{\circ} 19^{\prime} 02^{\prime \prime} \mathrm{N}, 11^{\circ} 15^{\prime} 42^{\prime \prime} \mathrm{E}\right)$ in 1985 at a water depth of $2833 \mathrm{~m}$. This core had been the subject of various studies including measurements of ${ }^{10} \mathrm{Be}$ (Castagnoli et al. 1995), carbonate content (Castagnoli et al. 1992), and magnetic properties (Castagnoli et al. 1998).

Samples were taken at the Turin Laboratory in 1992, 1993, and 1998 for our original study. More recently, in 2009, the second half of the core CT85-5 was sampled. For each ${ }^{14} \mathrm{C}$ analysis, at least 2000 specimens of Globigerina bulloides or mixed planktonic foraminifera were handpicked and processed for AMS analysis. In addition, 1 sample was prepared from pteropods, i.e. shells of pelagic sea snails (Table 1). Prior to sieving, the sediment was soaked in $10 \%$ solution of $\mathrm{H}_{2} \mathrm{O}_{2}$. Shells were then picked and treated in an ultrasonic bath of $\mathrm{H}_{2} \mathrm{O}$ to clean the surface and dissolved in concentrated (85\%) phosphoric acid. The weight of all the picked samples was over $20 \mathrm{mg}$, sufficient for preparation of targets that contained $2 \mathrm{mg}$ of pure carbon. Carbon dioxide was reduced to graphite (Hajdas et al. 2004b) and the ${ }^{14} \mathrm{C} /{ }^{12} \mathrm{C}$ ratios were measured using the ETH $6 \mathrm{MV}$ tandem accelerator (Bonani et al. 1987) and the 200kV MICADAS, which is a dedicated ${ }^{14} \mathrm{C}$ AMS instrument (Synal et al. 2007). Finite ${ }^{14} \mathrm{C}$ ages were obtained down to the layer of tephra at a depth of 290 $333 \mathrm{~cm}$ and then down to a depth of $359 \mathrm{~cm}$, where the limit of the ${ }^{14} \mathrm{C}$ dating method was reached for tandem measurements in the earlier stages of this study. The ages of the 6 deepest samples obtained in that set of data were indistinguishable from the background value (i.e. the measured ${ }^{14} \mathrm{C} /$ ${ }^{12} \mathrm{C}$ ratio of sample was smaller than double ${ }^{14} \mathrm{C} /{ }^{12} \mathrm{C}$ ratio of the blank). For these samples, activity was not corrected for the blank and the calculated ages are referred to as "older than" and are considered to be minimum ages (Figure 1, Table 1).

Table 1 Measured concentrations of ${ }^{14} \mathrm{C}\left(\mathrm{F}^{14} \mathrm{C}\right.$ as defined by Reimer et al. 2004) and radiocarbon ages of mixed planktonic foraminifera shells (samples made up of only Globigerina bulloides are marked as G. bull) and 1 pteropod shell sample from the deep-sea core CT85-5.

\begin{tabular}{lclll}
\hline Lab nr & $\begin{array}{l}\text { Depth }^{\mathrm{a}} \\
(\mathrm{cm})\end{array}$ & $\mathrm{F}^{14} \mathrm{C}$ & $\begin{array}{l}{ }^{14} \mathrm{C} \text { age } \\
(\mathrm{BP})\end{array}$ & Comments $^{\mathrm{b}}$ \\
\hline ETH-12683 & 95 & $0.30170 \pm 0.00383$ & $9625 \pm 100$ & \\
ETH-12261 & 100 & $0.27640 \pm 0.00272$ & $10,330 \pm 80$ & G. bull \\
ETH-19538 & 105 & $0.25800 \pm 0.00344$ & $10,880 \pm 110$ & \\
ETH-12262 & 111 & $0.25200 \pm 0.00320$ & $11,070 \pm 100$ & G. bull \\
ETH-12686 & 120 & $0.20918 \pm 0.00315$ & $12,570 \pm 120$ & G. bull \\
ETH-12688 & 139 & $0.18121 \pm 0.00257$ & $13,720 \pm 120$ & G. bull \\
ETH-12098 & 140 & $0.18214 \pm 0.00218$ & $13,680 \pm 95$ & \\
ETH-12689 & 147 & $0.15935 \pm 0.00226$ & $14,750 \pm 110$ & \\
ETH-12690 & 165 & $0.12564 \pm 0.00191$ & $16,660 \pm 120$ & \\
ETH-14163 & 180 & $0.10188 \pm 0.00162$ & $18,350 \pm 130$ & \\
ETH-14164 & 190 & $0.08093 \pm 0.00145$ & $20,200 \pm 140$ & \\
ETH-12691 & 200 & $0.05675 \pm 0.00138$ & $23,050 \pm 195$ & \\
ETH-13222 & 230 & $0.03738 \pm 0.00111$ & $26,400 \pm 240$ & \\
ETH-13223 & 250 & $0.02756 \pm 0.00111$ & $28,850 \pm 330$ & \\
ETH-13224 & 270 & $0.01732 \pm 0.00096$ & $32,580 \pm 450$ & \\
ETH-14048 & 275 & $0.01843 \pm 0.00085$ & $32,080 \pm 370$ & \\
ETH-37858 & 275 & $0.01590 \pm 0.00054$ & $33,265 \pm 275$ & 1,2 \\
ETH-14049 & 279 & $0.01794 \pm 0.00082$ & $32,300 \pm 370$ & \\
& & & &
\end{tabular}


Table 1 Measured concentrations of ${ }^{14} \mathrm{C}\left(\mathrm{F}^{14} \mathrm{C}\right.$ as defined by Reimer et al. 2004) and radiocarbon ages of mixed planktonic foraminifera shells (samples made up of only Globigerina bulloides are marked as G. bull) and 1 pteropod shell sample from the deep-sea core CT85-5. (Continued)

\begin{tabular}{lllll}
\hline Lab nr & $\begin{array}{l}\text { Depth }^{\mathrm{a}} \\
(\mathrm{cm})\end{array}$ & $\mathrm{F}^{14} \mathrm{C}$ & $\begin{array}{l}{ }^{14} \mathrm{C} \text { age } \\
(\mathrm{BP})\end{array}$ & Comments $^{\mathrm{b}}$ \\
\hline ETH-12099 & 280 & $0.01642 \pm 0.00065$ & $33,010 \pm 320$ & \\
ETH-13225.1 & 280 & $0.09058 \pm 0.00170$ & $19,290 \pm 150$ & \\
ETH-13225.2 & 280 & $0.08206 \pm 0.00143$ & $20,090 \pm 140$ & \\
ETH-19537.1 & 280 & $0.07071 \pm 0.00172$ & $21,280 \pm 195$ & \\
ETH-19537.2 & 280 & $0.08202 \pm 0.00128$ & $20,090 \pm 125$ & 2 \\
ETH-37859 & 280 & $0.09332 \pm 0.00086$ & $19,050 \pm 75$ & 1,2 \\
ETH-14050 & 282 & $0.03347 \pm 0.00103$ & $27,290 \pm 250$ & \\
ETH-17306.1 & 282 & $0.04071 \pm 0.00120$ & $25,710 \pm 240$ & Outside \\
ETH-17306.2 & 282 & $0.03885 \pm 0.00114$ & $26,090 \pm 240$ & Inside, $35 \%$ leached away \\
ETH-17307.1 & 283 & $0.11660 \pm 0.00177$ & $17,260 \pm 120$ & Outside \\
ETH-17307.2 & 283 & $0.11787 \pm 0.00176$ & $17,180 \pm 120$ & Inside $50 \%$ \\
ETH-24997.1 & 283 & $0.04760 \pm 0.00107$ & $24,460 \pm 180$ & \\
ETH-24997.2 & 283 & $0.05232 \pm 0.00124$ & $23,700 \pm 190$ & \\
ETH-24997.3 & 283 & $0.04398 \pm 0.00112$ & $25,095 \pm 205$ & 2 \\
ETH-24856.1 & 284 & $0.01677 \pm 0.00075$ & $32,840 \pm 360$ & Outside \\
ETH-24856.2 & 284 & $0.01773 \pm 0.00090$ & $32,390 \pm 410$ & Inside, $75 \%$ leached away \\
ETH-24856.3 & 284 & $0.02182 \pm 0.00109$ & $30,730 \pm 400$ & Pteropods \\
ETH-24856.4 & 284 & $0.02241 \pm 0.00078$ & $30,510 \pm 280$ & \\
ETH-37860 & 284 & $0.06021 \pm 0.00079$ & $22,570 \pm 105$ & 1,2 \\
ETH-12100.1 & 288 & $0.07324 \pm 0.00143$ & $21,000 \pm 160$ & \\
ETH-12100.2 & 288 & $0.05177 \pm 0.00207$ & $23,790 \pm 320$ & \\
ETH-12263 & 303 & $0.05395 \pm 0.00106$ & $23,760 \pm 180$ & G. bull \\
ETH-12264 & 314 & $0.04032 \pm 0.00122$ & $25,975 \pm 245$ & G. bull \\
ETH-38332 & 335 & $0.01126 \pm 0.00111$ & $36,040 \pm 790$ & 2 \\
ETH-12693 & 337 & $0.01181 \pm 0.00073$ & $35,660 \pm 500$ & G. bull \\
ETH-12694 & 344 & $0.01213 \pm 0.00076$ & $35,450 \pm 510$ & G. bull \\
ETH-10629 & 346 & $0.00768 \pm 0.00074$ & $39,110 \pm 770$ & \\
ETH-10630 & 352 & $0.00504 \pm 0.00069$ & $42,500 \pm 1100$ & \\
ETH-38333 & 358 & $0.00543 \pm 0.00106$ & $41,900 \pm 1570$ & 2 \\
ETH-10631 & 359 & $0.00588 \pm 0.00069$ & $41,260 \pm 940$ & \\
ETH-10634 & 381 & $0.00631 \pm 0.00044$ & $>40,690$ & \\
ETH-10635 & 385 & $0.00709 \pm 0.00048$ & $>39,760$ & \\
ETH-11970 & 388 & $0.00879 \pm 0.00039$ & $>38,030$ & \\
ETH-10636 & 395 & $0.00769 \pm 0.00049$ & $>39,100$ & \\
ETH-38334 & 395 & $0.00270 \pm 0.00026$ & $>47,520$ & 2 \\
ETH-37865 & 414 & $0.00453 \pm 0.00037$ & $>43,350$ & 2 \\
ETH-37866 & 459 & $0.00337 \pm 0.00036$ & $>45,720$ & 2 \\
\hline
\end{tabular}

${ }^{a}$ Top of the 1-cm slice of sediment.

${ }^{\mathrm{b}} 1=$ Additional samples 2009; 2 = AMS with MICADAS. 


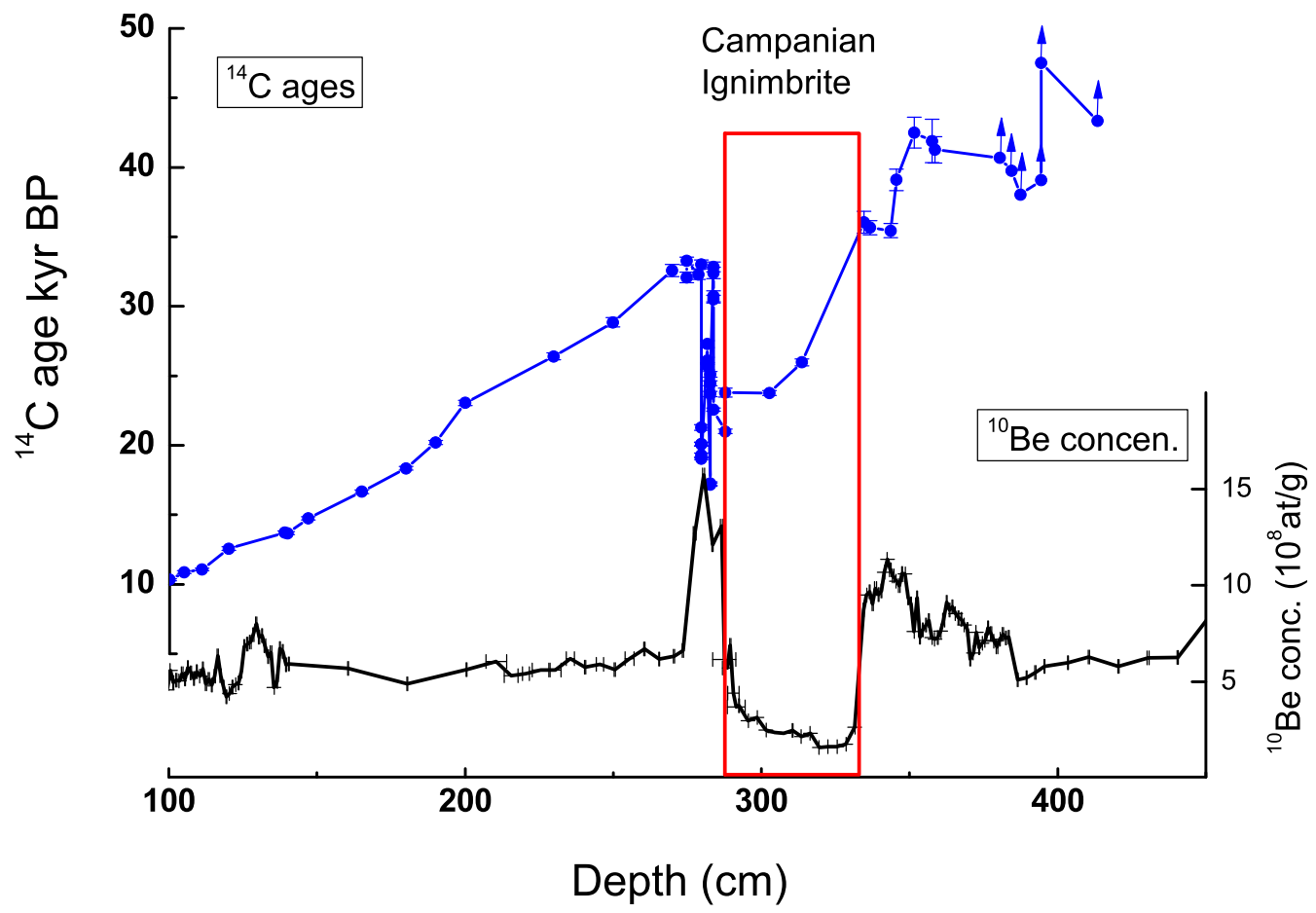

Figure $1{ }^{14} \mathrm{C}$ ages of planktonic foraminifera shells are plotted versus depth in core CT85-5: arrows show minimum ages (i.e. close to blank value, see Table 1). Lower panel shows concentration of ${ }^{10} \mathrm{Be}$ in sediments of CT85-5 (Castagnoli et al. 1995); the Campanian Ignimbrite is marked as a box. Note that this sediment layer, which is $43 \mathrm{~cm}$ thick, was an instantaneous deposit (see text).

\section{RESULTS}

The ${ }^{14} \mathrm{C}$ chronology of the last $40 \mathrm{ka}$ in the core CT85-5 shows regular features, but a reversal in ${ }^{14} \mathrm{C}$ ages appears between 280 and $336 \mathrm{~cm}$ (Figure 1), which corresponds to a zone containing the deposit of the Campanian Ignimbrite tephra layer $(290$ to $333 \mathrm{~cm}$ ) and just above the ash. Also, the interval partially overlaps with the layer where an enhanced ${ }^{10} \mathrm{Be}$ concentration in sediment was found (Castagnoli et al. 1995). As shown in Figure 1, a twofold ${ }^{10} \mathrm{Be}$ peak occurred: the ${ }^{10} \mathrm{Be}$ concentration increased within the interval $273-384 \mathrm{~cm}$ and then the increase was interrupted at 290$339 \mathrm{~cm}$ depth by the CI eruption (dilution effect of ${ }^{10} \mathrm{Be}$ atoms in the volcanic material). At $289 \mathrm{~cm}$, where the glass shards disappear, the ${ }^{10} \mathrm{Be}$ concentration increased as a spike, reaching its maximum value at $280 \mathrm{~cm}$ depth. We note that the highest ${ }^{14} \mathrm{C}$ content were reached at about the same depth, i.e. at $280-283 \mathrm{~cm}$. Because of the unusual magnitude of the age reversal, various tests have been performed to exclude any possible contamination as well as problems with measurements of very old samples.

Firstly, the possibility of contamination of the material is considered. The most probable source would be the deposition of secondary calcite on the surface of dated shells. We have performed leaching experiments of foraminifera in samples that had high ${ }^{14} \mathrm{C}$ content and appeared "too young." Our procedure involves on-line acidification of up to $50 \%$ of the sample material (surface) and subsequent separation of the produced $\mathrm{CO}_{2}$ from the remaining residue (inside) (Hajdas et al. 2004a). Both fractions of those samples were dated subsequently, showing no significant difference 
in ages between fractions (282 cm, ETH-17306; $283 \mathrm{~cm}, \mathrm{ETH}-17307$; and $284 \mathrm{~cm}, \mathrm{ETH}-24856)$ (Table 1).

A second potential reason for the younger ages is contamination with modern carbon and an underestimated blank correction. The blank values for IAEA marble C-1 for earlier measurements with the $\mathrm{EN}$ tandem were close to $0.005 \mathrm{~F}^{14} \mathrm{C}$ and samples stratigraphically older than those, showing enhanced ${ }^{14} \mathrm{C}$, i.e. below $333 \mathrm{~cm}$, were successfully dated (Figure 1). Moreover, measurements with the MICADAS system $\left(<0.003 \mathrm{~F}^{14} \mathrm{C}\right.$ on $\mathrm{C}$-1, IAEA marble) confirmed our earlier results (Table 1).

Our leaching experiments and duplicate analyses provide evidence that the enhanced ${ }^{14} \mathrm{C}$ levels in foraminifera shells deposited during or shortly after the volcanic eruption of Campanian Ignimbrite cannot be explained by limitations of the ${ }^{14} \mathrm{C}$ measurements or by contamination by secondary carbonates.

There is no plausible explanation for the intrusion of younger sediments into this section of the core. The sediments showing the inversed ages are $\sim 40 \mathrm{~cm}$ above the bottom of the core section; thus, contamination at the core break-off can be ruled out (Castagnoli et al. 1995). Additional measurements were obtained on samples from a nearby core CT85-6 (Table 2). The record of CT85-6 is shorter because the core was broken when penetrating the Campanian Ignimbrite. The ${ }^{14} \mathrm{C}$ ages in this core also show an inversion, however, not to such an extent as the one observed in CT85-5 (Figure 2).

Table 2 Concentrations of ${ }^{14} \mathrm{C}\left(\mathrm{F}^{14} \mathrm{C}\right)$ and radiocarbon ages measured on material from the core CT85-6 (mixed planktonic foraminifera). Correlation between cores was based on the Campanian Ignimbrite (CI) layer and $\mathrm{CaCO}_{3}$ (Castagnoli et al. 1992). The top of the $\mathrm{CI}$ layer is at $290 \mathrm{~cm}$ depth.

\begin{tabular}{llll}
\hline Lab nr & $\begin{array}{l}\text { Depth } \\
(\mathrm{cm})\end{array}$ & $\mathrm{F}^{14} \mathrm{C}$ & $\begin{array}{l}{ }^{14} \mathrm{C} \text { age } \\
(\mathrm{BP})\end{array}$ \\
\hline ETH-14165 & 270 & $0.02656 \pm 0.00078$ & $29,150 \pm 240$ \\
ETH-14166 & 275 & $0.02484 \pm 0.00079$ & $29,680 \pm 260$ \\
ETH-14167 & 280 & $0.02417 \pm 0.00074$ & $29,900 \pm 250$ \\
ETH-14051 & 286 & $0.01474 \pm 0.00078$ & $33,880 \pm 430$ \\
ETH-14597 & 287 & $0.01438 \pm 0.00077$ & $31,680 \pm 360$ \\
ETH-14598 & 289 & $0.01938 \pm 0.00087$ & $29,710 \pm 350$ \\
ETH-15197 & 290 & $0.01709 \pm 0.00096$ & $34,070 \pm 480$ \\
ETH-15198 & 292 & $0.01382 \pm 0.00083$ & $35,180 \pm 515$ \\
ETH-15051 & 293 & $0.02475 \pm 0.00108$ & $32,690 \pm 450$ \\
ETH-14052 & 295 & $0.01254 \pm 0.00080$ & $34,070 \pm 430$ \\
ETH-14599 & 296 & $0.01438 \pm 0.00077$ & $33,600 \pm 400$ \\
\hline
\end{tabular}

The presence of the tephra layer found in the CT85-5 core at 290-333 cm depth is important for our results because we can use it as a time marker. This layer, which has previously been correlated with the Campanian Ignimbrite (marine tephra C-13 or Y-5) (Castagnoli et al. 1995), has a lower carbonate content than the surrounding sediment (reduced to $\sim 25 \%$ ). Nevertheless, we were able to obtain 2 samples from this interval. Correlation of nearby Mediterranean deep-sea cores to North Atlantic cores showed that this eruption preceded Heinrich event 4 (Paterne et al. 1999).

As described in Castagnoli et al. (1995), the thick layer of trachytic glass admixed with carbonate mud is found in the CT85-5 core at depths between 333 and $290 \mathrm{~cm}$. The layer contains some grains of sanidine, plagioclase, biotite, and Na pyroxene. In the samples from this interval and sediment above it $(280-290 \mathrm{~cm})$, which had been washed for foraminifera, biotite and volcanic glass shards could be observed, confirming that inversed ${ }^{14} \mathrm{C}$ ages are associated with the ash layer. The chemical 


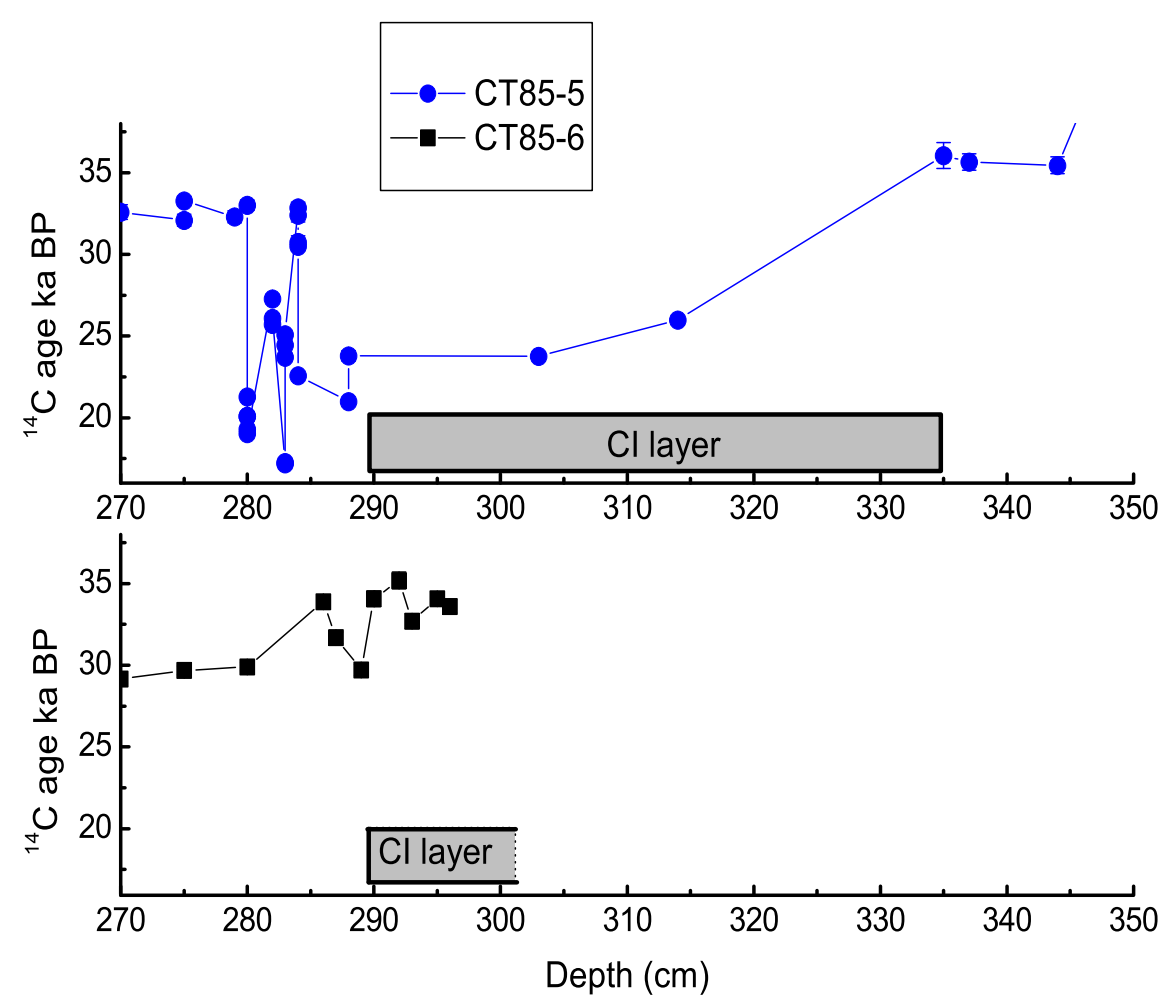

Figure 2 Reversed ${ }^{14} \mathrm{C}$ ages of planktonic foraminifera shells from the section in core CT85-5 core shown together with ${ }^{14} \mathrm{C}$ ages from a nearby core CT85-6. In both cores, the top of the CI tephra is at $290 \mathrm{~cm}$.

composition of the glassy material (Castagnoli et al. 1995) points to the Campanian Ignimbrite eruption in the Phleagrean Fields, which is a well-known stratigraphic marker in the Mediterranean region. This powerful eruption left distinct deposits of ash both on land and in marine sediments in the region (Barberi et al. 1978) and most probably had a large impact on the environments in the region. The first ${ }^{14} \mathrm{C}$ ages obtained on carbonized wood found in lava of the Campanian Ignimbrite had a large spread between 28 and 38 ka BP (Alessio et al. 1973, 1974). Other independent chronometers such as the ${ }^{40} \mathrm{~K} /{ }^{40} \mathrm{Ar}$ or ${ }^{40} \mathrm{Ar} /{ }^{39} \mathrm{Ar}$ dating method provided ages for the lava that ranged from 34 to $38 \mathrm{ka} \mathrm{cal} \mathrm{BP} \mathrm{(Wulf} \mathrm{et} \mathrm{al.} 2004$ and references cited therein). The most recent ${ }^{40} \mathrm{Ar} /{ }^{39} \mathrm{Ar}$ dating of the Campanian Ignimbrite ash revealed an age of $39.28 \pm 0.11 \mathrm{ka}$ cal BP (De Vivo et al. 2001) and $41.1 \pm 2.1 \mathrm{ka}$ cal BP (Ton-That et al. 2001).

\section{DISCUSSION}

The large change in ${ }^{14} \mathrm{C}$ concentration observed in the CT85-5 core appears to be a rather short event. In spite of its thickness of $43 \mathrm{~cm}$, the sediment layer in which the reversed ages were measured represents a very short event of volcanic eruption. Reversed ages are also found in the overlying $10 \mathrm{~cm}$ of sediments that have been described as turbidite deposits, probably associated with the $\mathrm{CI}$ event. Therefore, the short ${ }^{14} \mathrm{C}$ event observed in this core might be unique and difficult to replicate in other records. Most of the published records of the last 50,000 yr show evidence of an increase in atmospheric ${ }^{14} \mathrm{C}$ level that occurred around $40 \mathrm{ka}$ cal BP due to the Laschamp excursion, but no reversal (Hughen et al. 2004; Reimer et al. 2009 and references therein). However, one of the first published indications of an age reversal at $40.3-41.7 \mathrm{ka}$ cal BP is the record from core PS2644 
in the Icelandic Sea (Voelker et al. 2000). This event precedes Heinrich event 4 and has been correlated with low values of paleomagnetic intensity in PS2644 and, via $\delta^{18} \mathrm{O}$, with enhanced values of cosmogenic ${ }^{36} \mathrm{Cl}$ and ${ }^{10} \mathrm{Be}$ measured in ice cores (Wagner et al. 2000; Laj et al. 2002).

Other anomalously young ${ }^{14} \mathrm{C}$ ages have been observed and reported in marine sediments corresponding to the interval close to the Laschamp event ( $\sim 40 \mathrm{ka}$ cal BP$)$. For example, aberrant ${ }^{14} \mathrm{C}$ ages have been reported for paleomagnetic reconstructions in the Arctic Ocean sediment cores (Nowaczyk et al. 2003). This raises the question of whether the observed ${ }^{14} \mathrm{C}$ anomaly can be explained by the Laschamp event. However, model calculations show that switching off the geomagnetic dipole field increases the ${ }^{14} \mathrm{C}$ production rate by only about a factor 2.5 compared to the present-day production rate. To quantify these effects, we used a box diffusion carbon cycle model (Oeschger et al. 1975), which showed that a doubling in the production rate for 3 ka leads to an increase of the atmospheric ${ }^{14} \mathrm{C} /{ }^{12} \mathrm{C}$ ratio by about $40 \%$, corresponding to an age reduction by $3200 \mathrm{yr}$, which is much less than the observed 15,000 yr. Reducing the thermohaline circulation is more effective. A complete shutdown, which is a rather unrealistic assumption, leads to an annual increase of the atmospheric ${ }^{14} \mathrm{C} /{ }^{12} \mathrm{C}$ ratio by about $0.1 \%$, assuming the present production rate. A more realistic reduction of the eddy diffusion constant from the present value of 4000 to $1000 \mathrm{~m}^{2} \mathrm{yr}^{-1}$ causes an increase of about $0.01 \%$ per year. In conclusion, neither a change in the production rate nor a drastic reduction in the global thermohaline circulation seems feasible to explain the observed dramatic change in ${ }^{14} \mathrm{C}$ measured in the CT85-5 record.

\section{CONCLUSIONS}

The ${ }^{14} \mathrm{C}$ chronology of the Mediterranean deep-sea core CT85-5 shows a period of reversed ${ }^{14} \mathrm{C}$ ages coinciding with high levels of ${ }^{10} \mathrm{Be}$ that were found in the sediments deposited before and after the eruption of the Campanian Ignimbrite $(\mathrm{CI})$. Based on the radiometric ages of the CI eruption $\left({ }^{40} \mathrm{~K} /\right.$ ${ }^{40} \mathrm{Ar}$ or ${ }^{40} \mathrm{Ar} /{ }^{39} \mathrm{Ar}$ ) and on stable isotopic correlations obtained for Mediterranean deep-sea cores, this extreme ${ }^{14} \mathrm{C}$ event can be dated to around $40 \mathrm{ka}$ cal BP. We note that, despite several anomalously young ages in other records, the amplitude of the ${ }^{14} \mathrm{C}$ changes measured in the foraminifera of the layer in the CT85-5 core is unique and has not yet been confirmed by any other data. We are convinced that these too-young ${ }^{14} \mathrm{C}$ ages are not the result of any analytical problems. Although a plausible mechanism that could explain such extreme reversals in ${ }^{14} \mathrm{C}$ age as observed in this core remains to be found, our results are presented here to stimulate discussion and comparison with other possibly unpublished studies.

\section{ACKNOWLEDGMENTS}

Susan Ivy Ochs supported this study with discussions, investigation of ash layer sediment and review of this manuscript. We are grateful to all members of the AMS group at ETH, for their continuous support of ${ }^{14} \mathrm{C}$ analysis. We dedicate this paper to the memory of Prof Giuliana Cini Castagnoli, who contributed significantly but could not complete this study.

\section{REFERENCES}

Alessio M, Bella F, Improta S, Belluomini G, Cortesi C, Turi B. 1973. University of Rome carbon-14 dates X. Radiocarbon 15(1):165-78.

Alessio M, Bella F, Improta S, Belluomini G, Calderoni G, Cortesi C, Turi B. 1974. University of Rome carbon-14 dates XII. Radiocarbon 16(3):358-67.

Barberi F, Innocenti F, Lirer L, Munno R, Santacroce R.
1978. The Campanian Ignimbrite: a major prehistoric eruption in the Neapolitan area (Italy). Bulletin of Volcanology 41(1):10-31.

Baumgartner S, Beer J, Masarik J, Wagner G, Meynadier L, Synal H-A. 1998. Geomagnetic modulation of the ${ }^{36} \mathrm{Cl}$ flux in the GRIP ice core, Greenland. Science 279(5355):1330-2. 
Bonani G, Beer J, Hofmann H, Synal H-A, Suter M, Wölfli W, Pfleiderer C, Junghans C, Münnich KO. 1987. Fractionation, precision and accuracy in ${ }^{14} \mathrm{C}$ and ${ }^{13} \mathrm{C}$ measurements. Nuclear Instruments and Methods in Physics Research B 29(1-2):87-90.

Bonhommet N, Zähringer J. 1969. Paleomagnetism and potassium argon age determinations of the Laschamp geomagnetic polarity event. Earth and Planetary Science Letters 6(1):43-6.

Castagnoli GC, Bonino G, Provenzale A, Serio M, Callegari E. 1992. The $\mathrm{CaCO}_{3}$ profiles of deep and shallow Mediterranean Sea cores as indicators of past solarterrestrial relationships. Nuovo Cimento della Societa Italiana di Fisica C-Geophysics and Space Physics 15(5):547-63.

Castagnoli GC, Albrecht A, Beer J, Bonino G, Shen C, Callegari E, Taricco C, Dittrich-Hannen B, Kubik P, Suter M, Zhu GM. 1995. Evidence for enhanced ${ }^{10} \mathrm{Be}$ deposition in Mediterranean sediments $35 \mathrm{kyr}$ BP. Geophysical Research Letters 22(6):707-10.

Castagnoli GC, Bonino G, Taricco C, Lehman B. 1998. Cosmogenic isotopes and geomagnetic signals in a Mediterranean sea sediment at 35000 y BP. Nuovo Cimento della Societa Italiana di Fisica C-Geophysics and Space Physics 21(2):243-6.

De Vivo B, Rolandi G, Gans PB, Calvert A, Bohrson WA, Spera FJ, Belkin HE. 2001. New constraints on the pyroclastic eruptive history of the Campanian volcanic Plain (Italy). Mineralogy and Petrology 73(1-3):4765

Giaccio B, Hajdas I, Peresani M, Fedele FG, Isaia R. 2006. The Campanian Ignimbrite tephra and its relevance for the timing of the Middle to Upper Palaeolithic shift. In: Conard NJ, editor. When Neanderthals and Modern Humans Met. Tübingen: Kerns Verlag. p 343-75.

Hajdas I, Bonani G, Hergessell Zimmerman S, Mendelson M, Hemming S. 2004a. ${ }^{14} \mathrm{C}$ ages of ostracodes from Pleistocene lake sediments of the Western Great Basin, USA - results of progressive acid leaching. $R a$ diocarbon 46(1):189-200.

Hajdas I, Bonani G, Thut J, Leone G, Pfenninger R, Maden C. 2004b. A report on sample preparation at the ETH/PSI AMS facility in Zurich. Nuclear Instruments and Methods in Physics Research B 223-224: $267-71$.

Hughen K, Lehman S, Southon J, Overpeck J, Marchal O, Herring C, Turnbull J. 2004. ${ }^{14} \mathrm{C}$ activity and global carbon cycle changes over the past 50,000 years. Science 303(5655):202-7.

Laj C, Kissel C, Mazaud A, Channell JET, Beer J. 2000. North Atlantic palaeointensity stack since $75 \mathrm{ka}$ (NAPIS-75) and the duration of the Laschamp event Philosophical Transactions of the Royal Society of London Series A 358(1768):1009-25.

Laj C, Kissel C, Mazaud A, Michel E, Muscheler R, Beer J. 2002. Geomagnetic field intensity, North Atlantic Deep Water circulation and atmospheric $\Delta{ }^{14} \mathrm{C}$ during the last 50 kyr. Earth and Planetary Science Letters 200(1-2):177-90.

McHargue LR, Damon PE, Donahue DJ. 1995. Enhanced cosmic-ray production of ${ }^{10} \mathrm{Be}$ coincident with the Mono Lake and Laschamp geomagnetic excursions. Geophysical Research Letters 22(5):659-62.

McHargue LR, Donahue D, Damon PE, Sonett CP, Biddulph D, Burr G. 2000. Geomagnetic modulation of the late Pleistocene cosmic-ray flux as determined by ${ }^{10} \mathrm{Be}$ from Blake Outer Ridge marine sediments. $\mathrm{Nu}$ clear Instruments and Methods in Physics Research B 172(1-4):555-61.

Nowaczyk NR, Antonow M, Knies J, Spielhagen RF. 2003. Further rock magnetic and chronostratigraphic results on reversal excursions during the last $50 \mathrm{ka}$ as derived from northern high latitudes and discrepancies in precise AMS ${ }^{14} \mathrm{C}$ dating. Geophysical Journal International 155(3):1065-80.

Oeschger H, Siegenthaler U, Schotterer U, Gugelmann A. 1975. A box diffusion model to study carbon dioxide exchange in nature. Tellus 27(2):168-92.

Paterne M, Kallel N, Labeyrie L, Vautravers M, Duplessy J-C, Rossignol-Strick M, Cortijo E, Arnold M, Fontugne M. 1999. Hydrological relationship between the North Atlantic Ocean and the Mediterranean Sea during the past 15-75 kyr. Paleoceanography 14(5):62638.

Raisbeck GM, Yiou F, Bourles D, Lorius C, Jouzel J, Barkov NI. 1987. Evidence for 2 intervals of enhanced ${ }^{10} \mathrm{Be}$ deposition in Antarctic Ice during the Last Glacial period. Nature 326(6110):273-7.

Reimer PJ, Brown TA, Reimer RW. 2004. Discussion: reporting and calibration of post-bomb ${ }^{14} \mathrm{C}$ data. Radiocarbon 46(3):1299-304.

Reimer PJ, Baillie MGL, Bard E, Bayliss A, Beck JW, Blackwell PG, Bronk Ramsey C, Buck CE, Burr GS, Edwards RL, Friedrich M, Grootes PM, Guilderson TP, Hajdas I, Heaton TJ, Hogg AG, Hughen KA, Kaiser KF, Kromer B, McCormac FG, Manning SW, Reimer RW, Richards DA, Southon JR, Talamo S, Turney CSM, van der Plicht J, Weyhenmeyer CE. 2009. IntCa109 and Marine09 radiocarbon age calibration curves, 0-50,000 years cal BP. Radiocarbon 51(4): 1111-50.

Robinson C, Raisbeck GM, Yiou F, Lehman B, Laj C. 1995. The relationship between ${ }^{10} \mathrm{Be}$ and geomagnetic field strength records in central North Atlantic sediments during the last $80 \mathrm{ka}$. Earth and Planetary Science Letters 136(3-4):551-7.

Singer BS, Guillou H, Jicha BR, Laj C, Kissel C, Beard BL, Johnson CM. 2009. ${ }^{40} \mathrm{Ar} /{ }^{39} \mathrm{Ar}$, K-Ar and ${ }^{230} \mathrm{Th}-$ ${ }^{238} \mathrm{U}$ dating of the Laschamp excursion: a radioisotopic tie-point for ice core and climate chronologies. Earth and Planetary Science Letters 286(1-2):80-8.

Synal H-A, Stocker M, Suter M. 2007. MICADAS: a new compact radiocarbon AMS system. Nuclear Instruments and Methods in Physics Research B 259(1): $7-13$ 
Ton-That T, Singer B, Paterne M. 2001. ${ }^{40} \mathrm{Ar} /{ }^{39}$ Ar dating of latest Pleistocene (41 ka) marine tephra in the Mediterranean Sea: implications for global climate records. Earth and Planetary Science Letters 184(34):645-58.

Valet J-P, Plenier G, Guérin G, Lefèvre JC, LeGoff M, Carter-Stiglitz B. 2007. Origin and age of the directions recorded during the Laschamp event in the Chaîne des Puys (France). Earth and Planetary Science Letters 259(3-4):414-31.

Voelker AHL, Grootes PM, Nadeau M-J, Sarnthein M. 2000. Radiocarbon levels in the Iceland Sea from 25 $53 \mathrm{kyr}$ and their link to the earth's magnetic field intensity. Radiocarbon 42(3):437-52.
Wagner G, Beer J, Laj C, Kissel C, Masarik J, Muscheler R, Synal H-A. 2000. Chlorine-36 evidence for the Mono Lake event in the Summit GRIP ice core. Earth and Planetary Science Letters 181(1-2):1-6.

Wulf S, Kraml M, Brauer A, Keller J, Negendank JFW. 2004. Tephrochronology of the 100ka lacustrine sediment record of Lago Grande di Monticchio (southern Italy). Quaternary International 122(1):7-30.

Yiou F, Raisbeck GM, Baumgartner S, Beer J, Hammer C, Johnsen S, Jouzel J, Kubik PW, Lestringuez J, Stiévenard M, Suter M, Yiou P. 1997. Beryllium 10 in the Greenland Ice Core Project ice core at Summit, Greenland. Journal of Geophysical Research 102(C12):26,783-94. 